\title{
Nietzsche in Law's Cathedral: Beyond Reason and Postmodernism
}

John Linarelli

Touro Law Center, jlinarelli@tourolaw.edu

Follow this and additional works at: https://digitalcommons.tourolaw.edu/scholarlyworks

Part of the Criminal Law Commons, Law and Economics Commons, Law and Philosophy Commons, Law and Psychology Commons, Legal History Commons, and the Legal Theory Commons

\section{Recommended Citation}

53 CATH. U. L. REV. 413

This Article is brought to you for free and open access by the Faculty Scholarship at Digital Commons @ Touro Law Center. It has been accepted for inclusion in Scholarly Works by an authorized administrator of Digital Commons @ Touro Law Center. For more information, please contact Iross@tourolaw.edu. 


\title{
NIETZSCHE IN LAW'S CATHEDRAL: BEYOND REASON AND POSTMODERNISM
}

\author{
John Linarelli ${ }^{+}$
}

Nietzsche had very little to say about law, and what he did say is fragmentary and sporadic. Nietzsche's philosophy, however, offers a basis for theorizing about law. This article uses Nietzsche's important works to interpret two major movements in legal thought. The first part of the article examines how Nietzsche's philosophy augments our understanding of deontological theories about the law. Nietzsche produced a substantial ethical theory. The second part of the article examines how Nietzsche's philosophy helps us to understand law and economics. Nietzsche had a great deal to say about the intellectual predecessor to law and economics, utilitarianism, and his critique of utilitarianism offers insights into law and economics and its intellectual history. Further, Nietzsche elaborated a philosophy of science that extends to and offers insights about "analytical" social sciences such as economics.

\section{INTRODUCTION}

Nietzsche wrote almost nothing explicitly about law. Unlike Kant, Hegel, and others, Nietzsche offered nothing like a philosophy of law. ${ }^{1}$ His limited asides setting forth explicit notions about law, if read without further investigation, reflect an austere Austinian positivism, perhaps reflecting the way law was conceptualized in nineteenth-century Europe, when the great codifications of France and Germany were the subject of

\footnotetext{
+ Associate Professor of Law, University of La Verne College of Law. I am grateful to Tad Beckman for his encouragement and for helping me to see the value of Nietzsche's philosophy. I also wish to thank Jay Mootz and Jane Egly for helpful comments. Finally, Christine Pente, a law student at La Verne, patiently waded through a draft and offered insights. All references to works by Nietzsche are to section numbers in those works, unless otherwise noted.

1. See, e.g., Immanuel Kant, The Philosophy of Law: An Exposition of the FundamentAl PRINCIPLES OF JURISPRUDENCE AS THE SCIENCE OF RIGHT (W. Hastie trans. 1887); GEORG W. F. HEgEL, PHILOSOPHY OF Right (T.M. Knox trans. 1967). It would be wrong to assume that Kant's later work on philosophy of law was one of his major contributions. For an overview of Kant's contribution to legal philosophy, see EDWIN W. PATTERSON, JURISPRUDENCE: MEN AND IDEAS OF THE LAW 376-403 (1953). Although the title of the Patterson text is dated, the text nevertheless provides a good basic overview.
} 
public intellectual discussion. ${ }^{2}$ In The Gay Science, Nietzsche conceives law as a force against Dionysian impulses and the true mores of a people. ${ }^{3}$ In On the Genealogy of Morals, Nietzsche hints at law as being necessary to protect against ressentiment. ${ }^{4}$ Nietzsche seems to say that law is meant to protect people of nobility from the "herd" or those with "reactive feelings." Walter Kaufmann, the most influential interpreter of Nietzsche's works, interprets Nietzsche to assume that "only the weak need to rely on the rules of others," and "[m]an, being unique by nature, should be able to generate his own standards, if only he were powerful enough." In Nietzsche's writings there is an almost total absence of any significant political philosophy. ${ }^{7}$ Nietzsche's philosophy, according to Berkowitz, applies to individuals. It is about the "best life." ${ }^{8}$ Nietzsche was a moral philosopher, arguably one of the most significant ever."

Although Nietzsche said almost nothing directly about law, contemporary legal theorists and philosophers have labeled him a pragmatist and a postmodernist. ${ }^{10}$ The discussion of Nietzsche in the

2. See, e.g., FRIEDRICH NiETZSCHE, ON THE GENEALOGy OF MORALS, First Essay $\S \S 10-14$ (Walter Kaufmann \& R. J. Hollingdale trans. 1967) [hereinafter GENEALOGY OF MORALS].

3. FRIEDRICH NiETZSChE, ThE GAY SCIENCE $\$ 43$ (Waiter Kaufmann trans. 1974) [hereinafter GAY SCIENCE].

4. GENEALOGY OF MORALS, supra note 2, Second Essay, § 11.

5. Id.

6. Walter KaUfMANN, Nietzsche: Philosopher, PSYCHOlOGist, ANTICHRIST 250 (4th ed. 1974).

7. See PETER BERKOWITZ, NIETZSCHE: THE ETHICS OF AN IMMORALIST 1-2 (1995); $c f$. Francis FuKuYAMA, THE END OF HISTORY AND THE LAST MAN 300-01 (1992). Walter Kaufmann did much to dispel the notion that Nietzsche's philosophy supported Nazism. See KAUFMANN, supra note 6, at 284.

8. BERKOWITZ, supra note 7, at 4.

9. Alasdair MACINTYRe, AfTER VirTue 113 (2d ed. 1984). The author wrote: For it was Nietzsche's historic achievement to understand more clearly than any other philosopher-certainly more clearly than his counterparts in Anglo-Saxon emotivism and continental existentialism-not only that what purported to be appeals to objectivity were in fact expressions of subjective will, but also the nature of the problems that this posed for moral philosophy. It is true that Nietzsche, as I shall later argue, illegitimately generalized from the condition of moral judgment in his own day to the nature of morality as such: and I have already said justifiably harsh words about Nietzsche's construction of that at once absurd and dangerous fantasy, the Übermensch. But it is worth noting how even that construction began from a genuine insight.

Id.

10. See, e.g., Jules L. COleman \& JefFrie G. Murphy, The Philosophy of LAW: AN INTRODUCTION TO JURISPRUDENCE 53 (1984) (placing Nietzsche in the discussion of critical legal studies and feminist jurisprudence and concluding that Nietzsche's "perspective on values" is that values are "simply a product of power relations" and that "there is no moral truth or objectivity and thus no point in taking 
legal literature is relatively scant, but still significant enough to be too much to survey for this article, given its plan."

As for judicial use of Nietzsche, two curious references appear in the opinions of Supreme Court Justice Antonin Scalia. ${ }^{12}$ Scalia has used Nietzsche to criticize the opinions of other Supreme Court Justices who he believes depart from rules relating to stare decisis. ${ }^{13}$ In Harper $v$. Virginia Department of Taxation, Scalia criticized a dissent Justice Sandra Day O'Connor wrote, in which Justice O'Connor argued against

morality very seriously as a fundamental source of social (including legal) evaluation and criticism"); DOUGLAS E. LITOWITZ, POSTMODERN PHILOSOPHY AND LAW 42-64 (1997) (describing Nietzsche as postmodernist).

11. Legal scholarship that deals with Nietzsche for its core discussion is sparse. Another work using Nietzsche's philosophy to critique natural law is Postmodern Philosophy and Law, by Douglas E. Litowitz. This Article differs substantially from Litowitz's work. To mention a few differences: I do not classify Nietzsche as a postmodernist, as does Litowitz. This Article focuses more narrowly on two natural law theorists; Litowitz's book is a wider critique. This Article provides a critique of legal consequentialism in Part II, which is absent from the Litowitz text.

In October 2001, the Yeshiva University, Cardozo School of Law held a conference, Nietzsche and Legal Theory, resulting in a substantial addition to legal literature on Nietzsche. The papers are published in Volume 24 of the Cardozo Law Review. A sampling of those papers are included here, along with other sources. See, e.g., Jeanne L. Schroeder, Can Lawyers be Cured? Eternal Recurrence and the Lacanian Death Drive, 24 CARdozo L. REv. 925 (2003); Francis J. Mootz III, Nietzschean Critique and Philosophical Hermeneutics, 24 CARDOZO L. REV. 967 (2003); Tatiana Flessas, Cultural Property Defined, and Redefined as Nietzschean Aphorism, 24 CARDOZO L. REV. 1067 (2003); Roger Berkowitz, Friedrich Nietzsche, the Code of Manu, and the Art of Legislation, 24 CARDozo L. REV. 1131 (2003); Theresa Aiello, Nietzsche and Salomé Laws of the Father: Sublimation, Narcissism and Idealization, 24 CARDOZO L. REV. 1183 (2003); Adam Thurschwell, Specters of Nietzsche: Potential Futures for the Concept of the Political in Agamben and Derrida, 24 CARDozo L. REV. 1193 (2003); Kyron Huigens, Nietzsche and Aretaic Legal Theory, 24 CARDOZO L. REV. 563 (2003); Wolfert von Rahden, Individual Law: On Some Aspects of Nietzsche's Juridical and Aesthetic Discourse, 24 CARDozo L. REV. 723 (2003); Jonathan Yovel, Gay Science as Law: An Outline for a Nietzschean Jurisprudence, 24 CARDOZO L. REV. 635 (2003); Adam Gearey, We Fearless Ones: Nietzsche and Critical Legal Studies, 11 L. \& CRITIQUE 167 (2000); Richard A. Posner, Past-Dependency, Pragmatism and Critique of History in Adjudication and Legal Scholarship, 67 U. CHI. L. REV. 573 (2000); Richard H. Weisberg, It's a Positivist, It's a Pragmatist, It's a Codifier! Reflections on Nietzsche and Stendhal, 18 CARDozo L. ReV. 85 (1996); Peter Berkowitz, On the Laws Governing Free Spirits and Philosophers of the Future: A Response to Nonet's "What is Positive Law?", 100 YALE L.J. 701 (1990); Philippe Nonet, What is Positive Law?, 100 YALE L.J. 667 (1990); RICHARD H. WEISBERG, THE FAILURE OF THE WORD: THE PROTAGONIST AS LAWYER IN MODERN FICTION 14-25, 32-33 (1984).

12. See Harper v. Va. Dep't of Taxation, 509 U.S. 86, 107 (1993) (Scalia, J., concurring); Planned Parenthood v. Casey, 505 U.S. 833, 996 (1992) (Scalia, J.).

13. Harper, 509 U.S. at 102-10 (Scalia, J., concurring); Casey, 505 U.S. at 995-1001 (Scalia, J.). 
a retroactive application of a Supreme Court decision. ${ }^{14}$ The majority held that federal retirees living in Virginia could assert, in their state tax refund claims, that a Supreme Court precedent applied retroactively. ${ }^{15}$ The Supreme Court had changed the law on state taxation of federal retirement benefits from a rule permitting taxation to one that did not. ${ }^{16}$ In criticizing O'Connor for objecting to the retroactivity of precedent, Scalia said:

That [the] original and enduring American perception of the judicial role sprang not from the philosophy of Nietzsche but from the jurisprudence of Blackstone, which viewed retroactivity as an inherent characteristic of the judicial power, a power "not delegated to pronounce a new law, but to maintain and expound the old one."17

In a stinging dissent in Planned Parenthood $v$. Casey, Scalia criticized the majority for following the precedent of the famous Roe v. Wade, which sets forth the parameters of when abortion is legal. ${ }^{18}$ Scalia stated:

The Imperial Judiciary lives. It is instructive to compare this Nietzschean vision of us unelected, life-tenured judges - leading a Volk who will be "tested by following," and whose very "belief in themselves" is mystically bound up in their "understanding" of a Court that "speak[s] before all others for their constitutional ideals" - with the somewhat more modest role envisioned for these lawyers by the Founders.

"The judiciary ... has ... no direction either of the strength or of the wealth of the society, and can take no active resolution whatever. It may truly be said to have neither Force nor Will, but merely judgment ...."

Scalia's scant references could be said to misinterpret Nietzsche, although, to be fair, Scalia was writing judicial opinions, not philosophical essays. ${ }^{20}$

14. Harper, 509 U.S. at 102-10 (Scalia, J., concurring) (criticizing Justice O'Connor's plurality opinion in Teague v. Lane, 489 U.S. 288 (1989)).

15. Id. at $89-90$.

16. Id. at $98-99$.

17. Id. at 107 (quoting 1 WILLIAM BLACKSTONE, COMMENTARIES ON THE LAWS OF ENGLAND 69 (1765)).

18. Planned Parenthood v. Casey, 505 U.S. 833, 995-96 (1992) (Scalia, J., concurring in part and dissenting in part) (criticizing the majority for following Roe v. Wade).

19. Id. at 996. The latter quotation is from The Federalist No. 78, pp. 393-94 (G. Wills ed. 1982). The prior quotations are from the majority opinion.

20. See Mootz, supra note 11, at 1040. In the context of Supreme Court decisions that have dealt with the legal status of gays and lesbians, Mootz contends that Scalia "offers what might appear at first glance to be a Nietzschean critique, cutting through surface 
This Article explores two themes using Nietzsche's philosophy, based roughly on how legal theory divides between consequentialist and deontological approaches. ${ }^{21}$ First, the Article examines how Nietzsche's philosophy deals with legal policy issues that are expressed in deontological terms. ${ }^{22}$ Here we must deal with the classic notions of fairness, equality, justice and like concepts. Second, the Article explores whether Nietzsche's philosophy has anything to say about the dominant present day mode of legal thinking - law and economics - a variation of utilitarianism. $^{23}$ Law and economics is consequentialist to the core. I do not contend that Nietzsche thought of law or anything else in a consequentialist-deontological dichotomy. I use these categories because of their relevance to contemporary legal theory.

The Article shows that Nietzsche's philosophy says a great deal about contemporary legal ideas and also that Nietzsche offered insights about law that were far ahead of their time. ${ }^{24}$ The digestion of Nietzsche's ideas by the legal scholars of his day was implausible. Yet his critiques of science and reason had much to say about the scientism in the German legal academy of his time, and about the method of juridical science that pervades some German and continental European thinking about the law. ${ }^{25}$ A discussion of Nietzsche's philosophy and German codification, however, is another article, one that centers on the philosophy of legal history. This Article applies Nietzsche's philosophy to contemporary Anglo-American legal thought.

\section{NiEtzsche AND DeOnTOlogical Legal PRinCIPLES}

"No law can be sacred to me but that of my nature."

$A$.

Whether morality does or should influence the content of legal rules is one of the more significant debates in jurisprudence. ${ }^{27}$ Answers such as

appearances to the clash of political power that subtends the doctrinal squabbles," but then concludes that Scalia does not offer Nietzschean or hermeneutical insights because he pits power against reason in the form of politics against doctrinal legal analysis. Id.

21. For a fuller explanation of consequentialist versus deontological approaches, see LOUiS KAPLOW \& STEVEN SHAVELL, FAIRNESS Versus WELFARE 38-58 (2002).

22. See infra Parts 1.A.-D.

23. See infra Parts II.A.-F. The view that law and economics is a variation on utilitarianism is contentious and perhaps not well accepted. See infra text accompanying notes $158-66$.

24. See infra Part I.D.

25. See infra note 163. See generally Part II. This Article does not provide this critique.

26. RalPh Waldo Emerson, Self Reliance (1841). 
"law should reflect the mores of society" are as tautological as they are certain to be uttered routinely in American law school classrooms. Aligned with the problem of the law-morality connection, concepts related to morality, such as fairness, justice, and equality, have an uncertain location in the legal realm. ${ }^{28}$ Nietzsche's moral philosophy offers insights on these concepts. ${ }^{29}$ To explain how, this article compares Nietzsche's philosophy to the writings of two of the more significant natural law scholars of the late twentieth century, John Finnis and Michael Moore. These two scholars were chosen because they represent two of the more prominent voices in the contemporary natural law tradition. ${ }^{30}$

In his most influential work, Natural Law and Natural Rights, Finnis sets forth a theory of natural law." Finnis writes in the Aquinian tradition. $^{32}$ He uses the word "law" in the term "natural law" to mean "any criteria of right judgment in matters of practice (conduct, or action), any standards for assessing options for human conduct as good or bad, right or wrong, desirable or undesirable, decent or unworthy." "Natural," according to Finnis, means that the criteria of right judgment in law are "normative prior to any human choices." 34 Such "prior

27. See generally BRIAN BIX, JURISPRUDENCE: THEORY AND CONTEXT 31-86 (3d ed. 2004).

28. Economic analysis of law, widely perceived as the dominant school of legal thought, sits squarely in opposition to justice or fairness-based approaches to the law. It bypasses the difficulties in determining what is just or fair in favor of assessing the efficiency properties of legal rules, and applying a dichotomous analysis of efficiency versus distribution as a substitute for analysis of justice or fairness. See infra Part II for an examination of economics of law as a species of utilitarianism. Because Nietzsche had much to say about utilitarianism, the critique of law and economics is carved out for special consideration in the next part.

29. See infra Part I.D.

30. I am grateful to Jay Mootz for pointing out that Lloyd Weinreb and Lon.Fuller offer other versions of natural law that can be more accommodating of Nietzschean philosophy because their versions do not strictly require the discovery of timeless natural law principles through reason. See Francis J. Mootz III, Law in Flux: Philosophical Hermeneutics, Legal Argumentation, and the Natural Law Tradition, 11 YALE J.L. \& HUMAN. 311, 313-14, 338-67 (1999). There are other natural law scholars that I omit from the analysis as well.

31. JOHN FINNIS, NATURAL LAW AND NATURAL RIGHTS 1 (1980).

32. Though many examples could be given, see in particular JOHN FINNIS, AQUINAS: MORAL, POLITICAL, AND LEGAL THEORY vii (1998) (commenting on the "fundamental superiority" of Aquinas to Plato, Aristotle, and others); see also Patrick McKinley Brennan, Arguing for Human Equality, 18 J. L. \& RELIGION 99 (characterizing Finnis as "perhaps the best known expositor of Aquinas's legal ideas today").

33. John Finnis, Natural Law: The Classical Tradition, in THE OXFORD HANDBOOK OF JURISPRUDENCE AND PHILOSOPHY OF LAW 1 (Jules Coleman \& Scott Shapiro eds. 2002) [hereinafter OXFORD HANDBOOK].

34. Id. 
standards are not the product of either individual or collective choosing or positing, and cannot be repealed, however much they may be violated, defied, or ignored." 35 To acknowledge these standards is to engage in "practical reason," which is the capacity of a person to act in response to reasons for action."

Practical reason is one of the seven basic goods in Finnis's moral theory: life, knowledge, play, aesthetic experience, sociability, practicable reasonableness, and religion. ${ }^{37}$ Finnis views these basic goods as "aspect[s] of authentic human flourishing, ... real (intelligent) reason[s] for action." own sake and not as means to other ends. ${ }^{39}$ They are based on the "acts of practical understanding in which we grasp the basic values of human existence and thus, too, the basic principles of all practical reasoning,"40 which seems to be an elaborate way of saying that they are based on human nature. From these basic goods, Finnis articulates nine "basic requirements of practical reasonableness" which are needed to guide humans to "discern moral reason in everyday life." To Finnis, the basic goods and the practicable principles are obvious, self-evident and unquestionable. ${ }^{42}$

What about unreasonableness? To Finnis, unreasonableness is "human, all too human." than fully what a human person can be." ${ }^{, 45}$ In addition:

Poor thinking and choosing not only fails to actualize to the full one's capacities to be intelligent and reasonable, but also results

35. Id. at 1-2.

36. Steven J. Burton, Law as Practical Reason, 62 S. CAL. L. REV. 747 (1989).

37. FINNIS, supra note 31, at 85-97.

38. Id. at 64; see Brian H. Bix, Natural Law: The Modern Tradition, in OxFORD HANDBOOK, supra note 33, at 85.

39. FINNIS, supra note 31, at 64-65.

40. Id. at 59 .

41. Id. at $100-26$.

These nine principles are: [1] adopting a coherent plan of life; [2] having no arbitrary preferences among values; [3] having no arbitrary preferences among persons; [4] maintaining a detachment from the specific and limited projects one undertakes; [5] not abandoning one's commitments lightly; [6] not wasting one's opportunities by using inefficient methods; [7] not choosing to do something that of itself does nothing but damage or impede the realization of or participation in one or more of the basic goods; [8] fostering the common good of one's community; [and] [9] acting in accordance with one's conscience.

Bix, supra note 38 , at 86 .

42. FINNIS, supra note 31 , at 59.

43. Finnis, supra note 33 , at 2.

44. Id.

45. Id. 
in actions or omissions which fail to respect and promote the humanity, the nature, of everyone they affect. A community in which the standards by which we identify such failure are violated is not flourishing as it might. Its members, whether they are those acting (and forbearing) or those who should have been benefited not harmed, do not fulfill their capacities. However typical of human affairs, such a condition is unnatural so far as it is disrespectful of human persons. It is unnatural because unreasonable, and unreasonable because neglectful of the good of persons, the good which is the subject-matter of practical reason's standards.

Add to these principles the "master principle of morality," that humans should act, choose, deliberate, and will only those possibilities which are "compatible with integral human fulfillment," which means "the fulfillment of all human beings and their communities, in all the basic human goods." 47 From this master principle several other principles arise, notably that one's motives should be rational and not involve revenge, that one should follow the Golden Rule (do to others as you would have them do to you), and do not do evil to further a good. ${ }^{48}$

Law fits into Finnis's theory as a system of practical reason embedded in a particular social institution. ${ }^{49}$ As a system of practical reason, law can be understood only from an internal perspective, "the way of thinking of someone who treats a rule as a reason for action." practical reason approach to law is to be contrasted with the approach of those who examine law from an external perspective, who typically view law "simply as a prediction or basis for prediction." The external or predictive approach is typically associated with such fields as law and economics and law and pragmatism. ${ }^{52}$

Michael Moore is a moral realist. ${ }^{53}$ He believes that moral truth is metaphysically real, and moral reality exists independent of our language. ${ }^{54}$ The words used in law and in language generally refer to objects that exist, and the existence of the objects is independent of any

46. Id. (emphasis in original).

47. FINNIS, supra note 31 , at 28.

48. Id. at 29.

49. Id. at 3-18; see also JOSEPH RAZ, PRACTICAL REASON AND NORMS 10-13 (rev. ed. 1990).

50. FINNIS, supra note 31, at 27 (emphasis in original).

51. Id.

52. See Ernest J. Weinrib, The Idea of Private Law 3-21 (distinguishing the internal from external perspective).

53. See, e.g., Michael S. Moore, The Interpretive Turn in Modern Theory: A Turn for the Worse?, 41 STAN. L. REV. 871 (1989).

54. Id. at 872 . 
social construction or belief systems of the persons who use or hear those words." Rights and duties, good and evil, are moral entities or "moral kinds." ".6 $\mathrm{A}$ moral kind is a moral theory that applies to a moral word, such as justice or good, which is based not on human conventions but on "the best theory we are able to articulate about what sort of quality ... [justice or good] really is." ${ }^{57}$ Moore is of the view that there are unique and determinate right answers to moral questions. ${ }^{58} \mathrm{He}$ considers legal reasoning to be a species of moral reasoning. ${ }^{59}$ In interpreting cases, statutes, and constitutions, judges and lawyers should look for the real nature of the things to which the words of the law refer. ${ }^{60}$ To get to the right answers in morality and law, Moore articulates a nonfoundationalist coherence theory of epistemology for determining a moral proposition, which seems to dilute his moral reality: a moral value has to be coherent with everything else we believe, in order to achieve the status of a moral value. ${ }^{61}$

\section{$B$.}

In classic Nietzsche fashion of avoiding a dichotomous way of conceptualizing the world, Nietzsche's philosophy both condemns and supports natural law. First, this Article sets forth the basic elements of Nietzsche's condemnation. Second, this Article shows how Nietzsche had a vision of the good that was ethically principled, although he used the terms "noble" or "noble morality" rather than "good." Nietzsche's concept of noble morality offers a reference point from which to make ethical judgments about legal rules.

Natural law necessarily must rest on the foundation that there are some a priori or metaphysically real principles that are true and axiomatic, that do not require proof or justification, and that do not require any human choices. ${ }^{62}$ These principles have value because they are "right" or "moral," and all we need to do is find them. ${ }^{63}$ Nietzsche

55. See Michael S. Moore, A Natural Law Theory of Interpretation, 58 S. CAL. L. REV. 277 (1985).

56. Michael Moore, Moral Reality, 1982 WiSC. L. REV. 1061, 1145 (1982).

57. Id.

58. Id. at 1149 .

59. Bix, supra note 38 , at 91 .

60. Id.

61. See id. at 90.

62. A casual review of Finnis's foundation text and the works of other natural law scholars provides the insight. $C f$. LLOYD L. WEINREB, NATURAL LAW AND JUSTICE $97-$ 126 (1987) ("natural law without nature").

63. Finnis contends that self-evident basic goods, such as knowledge, exist. Finnis, supra note 33, at 59. Moore contends that a metaphysical reality exists that is real and knowable, independent of our interpretations of it. Moore, supra note 56, at 1149. 
would find a priori or metaphysically real principles problematic. In The Gay Science, Nietzsche wrote:

Whatever has value in our world now does not have value in itself, according to its nature-nature is always value-less, but has been given value at some time, as a present-and it was we who gave and bestowed it. Only we have created the world that concerns man! $!^{64}$

Thus, to Nietzsche, values come into existence because of human choice. Knowledge is the result of numerous errors made throughout human history. ${ }^{65}$ Through time, some errors proved useful, others did not. ${ }^{66}$ Those who were lucky enough to stumble upon the useful errors survived, and in time their errors became wisdom. ${ }^{67}$ Says Nietzsche:

Such erroneous articles of faith, which were continually inherited, until they became almost part of the basic endowment of the species, include the following: that there are enduring things; that there are equal things; that there are things, substances, bodies; that a thing is what it appears to be; that our will is free; that what is good for me is also good in itself. $^{68}$

Wisdom is not based on a priori truth, but rather on accident, the "dice throw," illogic and error. ${ }^{69}$ There is no compelling moral state of affairs. ${ }^{70}$

64. GAY SCIENCE, supra note $3, \S 301$ (emphasis in original). In his preface to On the Genealogy of Morals, Nietzsche explains "his a priori" as "the question of where our good and evil really originated." GENEALOGY OF MORALS, supra note 2, Nietzsche's Preface, $\S 3$.

65. GAY SCIENCE, supra note $3, \S 110$.

66. Id. $\S \S 110-11$.

67. Id. $\$ 110$.

68. Id.

69. See, e.g., Friedrich Nietzsche, Thus Spoke Zarathustra: A Book for ALL AND NONE, Third Part, $\S 4$, "Before Sunrise" (Walter Kaufmann trans., 1995) [hereinafter THUS SPOKE ZARATHUSTRA]. Nietzsche wrote:

$O$ heaven over me, pure and high! That is what your purity is to me now, that there is no eternal spider or spider web of reason; that you are to me a dance floor for divine accidents, that you are to me a divine table for divine dice and dice players.

Id.; see also Gilles Deleuze, Nietzsche AND Philosophy 25-27 (Hugh Tomlinson trans. 1983).

70. Though there are many sources for this point, Nietzsche's Preface in his On the Geneology of Morals supports it nicely. Nietzsche explains that he is looking for the "origin of moral prejudices." GENEOLOGY OF MORALS, supra note 2, Nietzsche's Preface, $\$ 2$. Later in the Preface, he explains:

Let us articulate this new demand: we need a critique of moral values, the value of the values themselves must first be called into question .... One has taken the value of these "values" as given, as factual, as beyond all question; one has hitherto never doubted or hesitated in the slightest degree in supposing "the 
Knowledge is not rational, scientific, ahistorical or analytical; rather, knowledge is really interpretation that rises to the level of habit. Humankind began to question error-produced wisdom only later in its existence, and only in relatively recent times did the concept of "truth" emerge, which Nietzsche calls the "weakest form of knowledge." T1 To Nietzsche, "the strength of knowledge does not depend on its degree of truth, but on its age, on the degree to which it has been incorporated, on its character as a condition of life." $" 72$

One Nietzschean problem of truth in natural law is that of false consciousness. ${ }^{73}$ In The Gay Science Nietzsche questions whether the socalled realists "can forget your descent, your past, your training-all of your humanity and animality" in order to engage in the cold and sober analysis of reality. ${ }^{74}$ Realism is impossible because realists are burdened with the primordial baggage that exists in all humans. They do not understand how the world has its origins in the passions of former centuries. $^{75}$

Nietzsche would find Finnis's and Moore's emphasis on reason problematic. Nietzsche would find them all too Socratic. ${ }^{76}$ To Nietzsche,

good man" to be of greater value than "the evil man," of greater value in the sense of furthering the advancement and prosperity of man in general. But what if the reverse were true?

Id. $\S 6$. These sorts of statements are not to be misconstrued to suggest that evil villains such as Saddam Hussein are somehow good. Rather, Nietzsche was raising very sophisticated questions to challenge the moral philosophers of his day and of past ages.

71. GAY SCIENCE, supra note $3, \S 110$.

72. Id. (emphasis in original).

73. The Cambridge Dictionary of Philosophy defines "false consciousness" as:

(1) lack of clean awareness of the source and significance of one's beliefs and attitudes concerning society, religion, or values; (2) objectionable forms of ignorance and false belief; (3) dishonest forms of self deception. Marxists (if not Marx) use the expression to explain and condemn illusions generated by unfair economic relationships .... Collingwood interprets false consciousness as selfcorrupting untruthfulness in disowning one's emotions and ideas.

ThE CAMBridge Dictionary of Philosophy (Robert Audi, ed., 2d ed. 1999).

74. GAY SCIENCE, supra note $3, \S 57$.

75. Id.

76. Kaufmann contends that Nietzsche admired Socrates. In his famous book, Kaufmann wrote an entire chapter on "Nietzsche's Attitude toward Socrates." KAUFMANN, supra note 6, at 391-411. Even Kaufmann concedes, however, that Nietzsche finds Socrates "deeply problematic." Walter Kaufmann, Translator's Introduction, in FRIEDRICH NiETZSCHE, THE BIRTH OF TRAGEDY 12 (Walter Kaufmann trans., Random House 1967) (1872) [hereinafter BIRTH OF TRAGEDY]. Socrates was problematic for Nietzsche because of Socrates' "faith" in reason. To Nietzsche, Socrates is in part responsible for the death of tragic art. Nietzsche's main concern was with "aesthetic Socratism," the "supreme law" of which is "to be beautiful everything must be intelligible." Id.; see also ARTHUR C. DANTO, NIETZSCHE AS PHILOSOPHER 57-58 (1965). Nietzsche disfavored Socratic emphasis on reason, at least as a basis for creating and 
Finnis's basic goods and requirements of practical reasonableness, ${ }^{77}$ and Moore's moral reality, would turn life into something like a play by Euripides. $^{78}$ Nietzsche blames Euripides for the destruction of Greek tragedy. $^{79}$ To Nietzsche, the problem with Euripides was that he abandoned the focus of Greek tragedy on the heroic in favor of glorifying the affairs of the common man, ${ }^{80}$ producing plays that were rational, comprehensible, and realistic in their portrayal of everyday life and its imperfections. ${ }^{81}$ Nietzsche saw the death of tragedy in Euripides because of the lack of Dionysian elements in Euripides' plays. ${ }^{\mathrm{X} 2}$ Moore and Finnis represent the embodiment of the Apollonian approach, and seek to remove the Dionysian element from the human state of affairs. ${ }^{83}$

Finally, Nietzsche would find problematic the moral principles that Finnis and Moore contend exist. ${ }^{84}$ Natural law fits nicely within Nietzsche's conception of "slave morality." Natural law is the belief system of the "last man" - it is "human all too human." To Finnis, to be unreasonable would be "human, all too human." Nietzsche takes the opposite view; to be reasonable is human, all too human. The reasonable person is the "last man," someone satisfied with happiness, striving for mediocrity and moderation. ${ }^{87}$ Nietzsche no doubt would refer to natural law as "the brain-sick fancies of morbid cobweb spinners." Nietzsche is by natural law standards immoral, but, as we shall see, he is nevertheless ethically principled.

C.

To produce strident criticism of anything requires contrary positions, and Nietzsche clearly had them. Despite his diatribes, his despising of systematic knowledge, and his scathing ad hominem attacks, Nietzsche

experiencing art. Nietzsche admired Socratic accomplishment of focusing mankind on reason, because the alternatives would lead to a worse state of affairs. Id. at 59 .

77. See generally FINNIS, supra note 31 .

78. BIRTH OF TRAGEDY, supra note $76, \S 12$; see also KAUFMANN, supra note 6 , at 393.

79. DANTO, supra note 76 , at 57.

80. BERKOWITZ, supra note 7 , at 59 .

81. Id.; DANTO, supra note 76, at 58 .

82. DANTO, supra note 76 , at 59.

83. See generally FINNIS, supra note 31.

84. See generally id.

85. One of the most fundamental tenets of Nietzsche's philosophy is the distinction between slave and noble morality. See infra text accompanying notes 122-41, 168-72.

86. See FINNIS, supra note 31.

87. DANTO, supra note 76, at 197; BERKOWITZ, supra note 7, at 142-43.

88. Friedrich NiETzSCHE, Reason in Philosophy, in Twilight OF THE IDOLS $\S 4$ (R.J. Hollingdale trans., Penguin Books 1968). 
constructed an ethical philosophy. ${ }^{89}$ He had an elaborate vision of the truth and saw man as being able to choose, and choice as necessary for being. ${ }^{\text {() }}$ Structuralism was not part of his philosophy, nor was instrumentalism. Contrary to postmodern interpretations of his work, Nietzsche was not a nihilist, though he did attack norms and standards by which he saw nineteenth-century Europeans guiding their actions." Nietzsche did not reject value commitments, though his values differ from what he calls the herd or slave morality of Christianity and Enlightenment philosophy. ${ }^{92}$ His elaborations on how the concept of "good" began in primordial history reflecting the qualities of elites, then to be rejected in the slave revolt in morality and the rise of ressentiment, set forth an ethical agenda. ${ }^{93}$ Nietzsche's last man is to be contrasted with his overman, who seeks not to dominate but to go beyond and to become noble. $^{94}$ The overman is not interested in hurting others; his nobility is about transcending the human condition rather than concerning himself with the lives of others. ${ }^{9.5}$

Nietzsche's works set forth an elaborate "noble mode of valuation" and a noble morality that Russell and Kaufman find akin to the virtuous life that Aristotle articulates in the Nicomachean Ethics. ${ }^{97}$ Nietzsche's core philosophical conceptions are will to power, overcoming and eternal recurrence. ${ }^{48}$ These conceptions are ethical principles that mandate value commitments. Heidegger viewed Nietzsche as one of the most important metaphysical thinkers in Western philosophy. ${ }^{99} \mathrm{He}$ also is one of the most important moral philosophers in Western philosophy. ${ }^{100}$ Here, this Article examines the affirmative side of Nietzsche's philosophy.

Will to power is the struggle of humans over time to learn and develop norms of behavior through species preserving error. ${ }^{101}$ It is both creative and destructive. ${ }^{112}$ It creates because humans use will to power to

89. See generally GENEAOLOGY OF MORALS, supra note 2.

90. Id.

91. Id.

92. See BERKOWITZ, supra note 7, at 141-44.

93. See GENEALOGY OF MORALS, supra note 2, First Essay, $\S 10$.

94. DANTO, supra note 76 , at 197.

95. Id.

96. GeneOlogy OF MORALS, supra note 2, First Essay, $\$ 10$.

97. See infra text accompanying notes 130-42.

98. Tad Beckman, Notes for Nietzsche, at http://www.4hmc.edu:8001/ humanities/beckman/nietzsche/reading/also.htm (last visited Oct. 2, 2003).

99. 2 MARTIN HEIDEGGER, NiETzSCHE 1 (David Farrell Krell trans., Harper \& Row 1984) (1954).

100. See supra note 10 and accompanying text.

101. Beckman, supra note 98.

102. Id. 
produce values and to make sense of existence. ${ }^{103}$ It destroys because it must overcome old values that no longer serve us. ${ }^{104}$ Nietzschean will to power differs fundamentally from natural law philosophy because the world is chaotic and we cannot understand it through reason. ${ }^{105}$ There is no right reason or moral reality that we must ultimately discover if we think or try hard enough. ${ }^{106}$ Heidegger interprets Nietzsche's will to power as designating the basic character of being; it is the basic question of the being of beings. ${ }^{107}$

Will to power is a mode of valuation, a method, but not value itself. ${ }^{108}$ It does not tell us what is right and wrong, ideas that are uncomfortable in Nietzschean philosophy because they presuppose that values can be sufficiently general or "right." 109 To Heidegger, will to power has to be thought of together with Nietzsche's eternal recurrence in order to fully grasp Nietzsche's philosophy. ${ }^{110}$ Using Heidegger's conception of Nietzsche's philosophy, we now can see the conceptual glue being set on Nietzsche's ethics. ${ }^{111}$ When will to power and eternal recurrence are read together, they give us a way of being or operating as does Finnis's practical reasonableness. ${ }^{112}$

Heidegger contended that the idea of the eternal recurrence was the fundamental thought in Nietzsche's philosophy. ${ }^{113}$ Although Nietzsche explained it allegorically in Thus Spoke Zarathustra, ${ }^{114}$ he described eternal recurrence succinctly in Ecce Homo as "the unconditional and infinitely repeated circular course of all things." 115 Though Nietzsche for a time wanted to prove eternal recurrence scientifically, as a physical

103. Id.

104. Id.

105. Id.

106. Id. Will to power is the fundamental human ability to struggle through the incomprehensible accident of the world to make life sensible and practical.

107. 1 HEIDEGGER, supra note 99 , at 18-21.

108. Thus SPOKe ZARAThuSTRA, supra note 69, Second Part; Tad Beckman, Notes on Thus Spoke Zarathustra, at http:/www4.hmc.edu:8001/humanities/beckman/ nietzsche/reading/Also.html.

109. 1 HEIDEGGER, supra note 99.

110. Id.

111. Id. at 18.

112. See generally Notes for Nietzsche, supra note 98; FiNNIS, supra note 31 . Both sets of principles have to do with how to live life.

113. 2 HeidegGer, supra note 99, at 5. Nietzsche called his idea of the eternal recurrence a "doctrine."

114. ThUS SPOKE ZARATHUSTRA, supra note 69, Third Part, "On the Vision and the Riddle."

115. FRIEDRICH NiETzSCHE, ECCE HOMO, Essay on Birth of Tragedy, § 3 (Walter Kaufmann trans. 1966) [hereinafter ECCE HOMO]. 
law, ${ }^{166}$ he ultimately settled for leaving it as an ethical precept, about a way of life. ${ }^{117}$ Because what we do eternally returns, every moment counts. ${ }^{118}$ Eternal recurrence gives direction to will to power. ${ }^{119}$ We now must promote the highest order of values possible, because what we do now will return in the future. ${ }^{120}$

Finally, Nietzsche specified a set of values for humans to seek to achieve through will to power. He does not see the essence of life in self preservation, but in enhancement of life. ${ }^{121}$ Nietzsche was not a moral skeptic. ${ }^{122}$ Humans must overcome; the goal is becoming overman, not to model one after a saint or God. ${ }^{123}$ Noble values are embodied in the idea of a noble morality, which is to be contrasted with slave or herd morality. ${ }^{124}$ The noble moral person is one who has a strong character, a "great souled" character in the style of the Athenian citizen. ${ }^{125}$ The noble moral person triumphs over ressentiment. To avoid ressentiment is an ethical precept. ${ }^{126}$ To be kind, humble or silent when one is too weak or timid to act, to be humble when one cannot bear unpleasant repercussions, to make virtue of necessity, to want revenge against the teacher, to have reactive feelings, to be resentful, and to seek and give pity, Nietzsche identified these as attributes of slave morality. ${ }^{127}$ To quote Nietzsche, through his Zarathustra:

But if you have an enemy, do not requite him evil with good, for that would put him to shame. Rather prove that he did you some good.

And rather be angry than put to shame. And if you are cursed, I do not like it that you want to bless. Rather join a little in the cursing.

116. 2 HEIDEGGER, supra note 99 , at 106-09.

117. 2 HEIDEGGER, supra note 99, at 122-23.

118. Beckman, supra note 108.

119. See 3 HEIDEGGER, supra note 99.

120. Beckman, supra note 108.

121. 3 HEIDEGGER, supra note 99 , at 15 .

122. This is perhaps one of the central themes in BERKOWITZ, supra note 7.

123. DANTO, supra note 76, at 196-97.

124. GENEALOGY OF MORALS, supra note $2, \S 10$.

125. See infra text accompanying notes 131-39.

126. See 3 HEIDEGGER, supra note 99 . In essence, it means that one should be strong and magnanimous.

127. KAUFMANN, supra note 6, at 371-72. 
And if you have been done a great wrong, then quickly add five little ones: a gruesome sight is a person single-mindedly obsessed by a wrong.

Did you already know this? A wrong shared is half right. And he who is able to bear it should take the wrong upon himself.

A little revenge is more human than no revenge. And if punishment is not also a right and an honor for the transgressor, then I do not like your punishments either.

It is nobler to declare oneself wrong than to insist on being right-especially when one is right. Only one must be rich enough for that.

I do not like your cold justice; and out of the eyes of your judges there always looks the executioner and his cold steel. Tell me, where is that justice which is love with open eyes? Would that you might invent for me the love that bears not only all punishment but also all guilt! Would that you might invent for me the justice that acquits everyone, except him that judges!

Do you still want to hear this too? In him who would be just through and through even lies become kindness to others. But how could I think of being just through and through? How can I give each his own? Let this be sufficient for me: I give each my own. ${ }^{128}$

In On the Genealogy of Morals, Nietzsche says:

While the noble man lives in trust and openness with himself (gennaios "of noble descent" underlines the nuance "upright" and probably also "naive"), the man of ressentiment is neither upright nor naive nor honest and straightforward with himself. His soul squints; his spirit loves hiding places, secret paths and back doors, everything covert entices him as his world, his world, his security, his refreshment; he understands how to keep silent, how not to forget, how to wait, how to be provisionally self-deprecating and humble. A race of such men of ressentiment is bound to become eventually cleverer than any

128. Thus SPOKe ZaRAthustra, supra note 69, First Part, "On the Adder's Bite" 68-69. 
noble race; it will also honor cleverness to a far greater degree: namely, as a condition of existence of the first importance ....

To be incapable of taking one's enemies, one's accidents, even one's misdeeds seriously for very long-that is the sign of strong, full natures in whom there is an excess of the power to form, to mold, to recuperate and to forget ... . Such a man shakes off with a single shrug many vermin that eat deep into others; here alone genuine "love of one's enemies" is possiblesupposing it to be possible at all on earth. How much reverence has a noble man for his enemies!-and such reverence is a bridge to love. ${ }^{129}$

Such ideas permeate Nietzsche's works; the above extracts capture the essential concepts.

Russell and Kaufmann compare Nietzsche's concept of the noble man to Aristotle's great souled or magnanimous man found in Book IV of Aristotle's Nicomachean Ethics. ${ }^{130}$ Aristotle refers to "greatness of soul," an upper class Greek virtue that has no direct translation into present day English, but which is close to magnanimity, proper pride or selfrespect. ${ }^{131}$ The great souled or magnanimous man "thinks that he is worthy of great things, provided that he is worthy of them."132 "The man who is worthy of little consideration and thinks that he is such is temperate [moderate], but not magnanimous, because magnanimity implies greatness ...." ${ }^{133}$ Aristotle identifies a number of characteristics

129. GENEALOGY OF MORALS, supra note 2, First Essay, $\$ 10$ (emphasis in original).

130. Kaufmann, supra note 6 , at 382-83; BERTRAND RUSSELL, A HISTORY OF WESTERN PHILOSOPHY 176 (1945).

131. ARistotle, The Nicomachean EthiCs 153 (J. A.K. Thomson trans. 1933) (Translator Notes). The word in ancient Greek is megalopsuchia. Though Thomson translates this word to mean magnamity, Rackham says that it means "lofty pride and selfesteem rather than magnamity or high-mindedness (in the modern sense of the word)." Compare id., with ARISTOTLE, NichOMACHEAN ETHICS 213 n.b (H. Rackham trans., 1933).

132. ARISTOTLE, NiCOMACHEAN ETHICS (Thomson trans.), supra note 131, at $\S 1123 \mathrm{a} 31-\mathrm{b} 13$.

133. Id. Aristotle continues:

The man who thinks that he is worthy of great things although he is not worthy of them is conceited; but not everybody is conceited who has too high an opinion of his own worth. On the other hand the man who has too low an opinion is pusillanimous: and it makes no difference whether his worth is great or moderate or little, if his opinion of it is too low. Indeed the man whose worth is great might be regarded as especially pusillanimous, because what would his behaviour be if his worth were not so great? 
of the great souled or magnanimous man in his Book IV..$^{134}$ Of Aristotle's magnanimous man, Russell remarked, "One shudders to think what a vain man would be like." 135 The connection between Aristotle's and Nietzsche's ethics seem clear. ${ }^{136}$ Nietzsche, like Aristotle, is not concerned with how to make people "good" or "moral," but rather

134. Id. $\S \S 1124 \mathrm{a} 23-\mathrm{b} 14$ to $1125 \mathrm{a} 5-27$.

The magnanimous man does not take petty risks, nor does he court danger, because there are few things that he values highly; but he takes great risks, and when he faces danger he is unsparing of his life, because to him there are some circumstances in which it is not worth living. He is disposed to confer benefits, but is ashamed to accept them, because the one is the act of a superior and the other that of an inferior. When he repays a service he does so with interest, because in this way the original benefactor will become his debtor and beneficiary. People of this kind are thought to remember the benefits that they have conferred, but not those that they have received (because the beneficiary is inferior to the benefactor, and the magnanimous man wants to be superior), and to enjoy being reminded of the former, but not of the latter .... Another mark of the magnanimous man is that he never, or only reluctantly, makes a request, whereas he is eager to help others. He is haughty towards those who are influential and successful, but moderate towards those who have an intermediate position in society, because in the former case to be superior is difficult and impressive, but in the latter it is easy; and to create an impression at the expense of the former is not ill-bred, but to do so among the humble is vulgar-like using one's strength against the weak .... He is bound to be open in his likes and dislikes (because concealment, i.e. caring less for the truth than for what people think, is a mark of timidity), and to speak and act straightforwardly (his superior attitude makes him outspoken and candid ... ); and he cannot bear to live in dependence upon somebody else, except a friend, because such conduct is servile; which is why all flatterers are of the lowest class, and humble people are flatterers. He is not prone to express admiration, because nothing is great in his eyes. He does not nurse resentment, because it is beneath a magnanimous man to remember things against people, especially wrongs; it is more like him to overlook them. He does not care for personal conversation; he will talk neither about himself nor about anyone else, because he does not care to be complimented himself or to hear others criticized; nor again is he inclined to pay compliments. For this reason he is not abusive either, not even of his enemies, unless he intends to be insulting. In troubles that are unavoidable or of minor importance he is the last person to complain or ask for help, because such an attitude would imply that he took them seriously.

Id.

135. RUSSELL, supra note 130.

136. I am not the first, and probably not the last, to see this. See id. at 175. In After Virtue, MacIntyre argues that the moral philosophies of Nietzsche and Aristotle present "two genuine theoretical alternatives confronting anyone trying to analyze the moral condition of our culture." MacIntyre, supra note 9, at 110. MacIntyre contends that to Nietzsche, modern moral utterance is specific to the person, not determined by reason but by will. In the end, MacIntrye rejects Nietzsche. His logic: The Enlightenment philosophers tried to repudiate Aristotle, but they failed. Nietzsche tried to repudiate the Enlightenment philosophers, which needed to be done because the Enlightenment was a failure. So, our only alternatives are Nietzsche or Aristotle, and certainly we cannot accept Nietzsche. Id. at 109-20 (chapter entitled "Nietzsche or Aristotle?"). 
with how one is to be a successful human being. ${ }^{137}$ Aristotle's virtuous person was not a Christian saint, nor was Nietzsche's. ${ }^{138}$

Finally, Nietzsche had no concern about the common good. Nietzsche's herd or slave morality is good for the group or collective but not for the individual; noble morality is about how to make the individual better off, regardless of what the community might need from the individual. ${ }^{139}$ But is Nietzsche in this respect so different from any other nonconsequentialist philosopher? Aristotle, clearly not utilitarian, examines the virtues of the good person from the standpoint of the person who has, or lacks, the virtue, and is not concerned with the effects of the virtue on other persons. His discussions of generosity or courage in Nichomachean Ethics, for example, consider these virtues only from the perspective of the agent possessing these qualities and not from the perspective of how these qualities are necessary to protect society. ${ }^{140}$ Aristotle's concept of the common good is fused with his concept of private good: what is a good virtue for the individual is good for the city. $^{141}$

$D$.

What do Nietzsche's ethics say about law? If natural law is slave or herd morality, and if we accept that natural law is or should inform the content of positive law, then we must conclude that positive law is or should be based on herd morality. Law is meant primarily for society and can harm persons striving for a noble morality. Nietzsche would ask us to develop a new jurisprudence that preserves freedom to overcome, to pursue noble morality. ${ }^{142}$ Positive law can be constructed in such a way because Nietzsche viewed norms embodied in morals and law as social constructions. ${ }^{143}$ Nietzsche would prefer a legal system that disables and avoids ressentiment, that would promote human freedom in a pluralist setting without interpersonal comparisons. ${ }^{144}$ Nietzsche's normative vision is that we should fundamentally reevaluate law and other social systems and reorient towards a noble morality.

137. See ARISTOTLE, supra note 131, Translator's Introduction, at 29.

138. RUSSELL, supra note 130 , at 175.

139. GENEALOGY OF MORALS, supra note 2, Second Essay, $\$ 2$.

140. See ARISTOTLE, NICOMACHEAN ETHICS (Thomson trans.), supra note 131, at 31. This is implicit in Aristotle's concept of eudaimonia. See J.L. Ackrill, Aristotle on Eudaimonia, in ARISTOTLE'S ETHICS: CRITICAL ESSAYS (Nancy Sherman ed., 1999).

141. ARISTOTLE, NICOMACHEAN ETHICS (Thomson trans.), supra note 131, $\S$ 1094a22-b12; MacIntyre, supra note 9, at 150.

142. See GENEOLOGY OF MORALS, supra note 2, Second Essay, §§ 2, 11.

143. Id.

144. Id. 
Nietzsche's discussion of the notion of equality provides an example of how we can use Nietzsche's legal theory to inquire about law. In several passages, Nietzsche expressed disfavor with the notion of equality. ${ }^{145}$ Nietzsche's thoughts on equality are important because the notion of formal equality and how to implement it pervades the ideal visions of Western legal systems. A fundamental aspect of the human condition that law seeks to address is which sorts of inequality deserve legal redress. Hence, constitutional law mandating equal protection and due process, statutes prohibiting discrimination and cases interpreting these statutes, and the recent affirmative action cases are but examples of the ongoing dialogue between law and society on what sorts of inequalities are permissible and which are not. ${ }^{146}$

In Thus Spoke Zarathustra, in a section entitled "On the Tarantulas," Nietzsche metaphorically describes "preachers of equality" as tarantulas whose "secretly vengeful" ways make "the soul whirl with revenge.",147 Nietzsche's main concern seems to be about dictatorial preferences: "You preachers of equality, the tyrannomania of impotence clamors thus out of you for equality: your most secret ambitions to be tyrants thus shroud themselves in words of virtue." "148 "I do not wish to be mixed up and confused with these preachers of equality. For to me justice speaks thus: 'Men are not equal.' Nor shall they become equal! What would my love of the overman be if I spoke otherwise?"149

These passages are easily misconstrued to suggest that Nietzsche was anti-liberal or racist. ${ }^{150}$ Nietzsche's conception of will to power does not mean that the strong should subjugate the weak or that there are inherent inequalities among peoples. Nietzsche saw values and the characteristics of humans as socially constructed, so it is difficult to read determinism into his philosophy. Rather, Nietzsche's concern with equality is twofold: first, the striving for equality is a search for the unattainable. People are different and can choose. Some will seek a noble life while others will practice ressentiment and bad conscience. ${ }^{151}$ If

145. See BEYOND GOOD AND EVIL $\$ \S 201-03,212,238$; THUS SPOKE ZARATHUSTRA, supra note 69 , at $99-100$.

146. U.S. CONST. amend. XIV; Grutter v. Bollinger, 539 U.S. 306 (2003); Gratz v. Bollinger, 539 U.S. 244 (2003).

147. Thus SPOKe Zarathustra, supra note 69 , Second Part, "On the Tarantulas" at 99 (emphasis in original).

148. Id. at 100 .

149. Id. (emphasis in original).

150. There are other more obvious and regrettable racist and sexist passages in Nietzsche's works. The problem with many Nietzsche interpretations, however, is selective misquoting. Nietzsche advised against this. GENEALOGY OF MORALS, supra note 2, Nietzsche's Preface, $\$ 8$, n.5.

151. See id. $\$ 10$ n.2. 
people are free they will make choices about which path to take. Second, in response to the democratic consolidation that started to take hold in Europe in the nineteenth century, Nietzsche is essentially asking the question "is that all there is?" To Nietzsche, equality works much like Christianity, to sap the life out of people, to make them comfortable, complacent, and to furnish incentives to compare their lot with others, even if their state of affairs is dismal, rather than to strive for a higher order on their own, without reference to what others have or do not have. ${ }^{152}$ In sum, to Nietzsche, equality is overrated.

But Nietzsche's criticism of equality is vague. His objection could be read as against egalitarianism, an idea important in nineteenth-century European socialist thought. It is doubtful that Nietzsche would have much interest in the minimum fairness standard of treating like cases alike, though if he were to have an interest, it is unlikely that he would strenuously object. ${ }^{153}$ Treating like cases alike does not impose the requirement that everyone must $b e$ the same; it only says that everyone must be treated the same if they are the same. ${ }^{154}$ Nietzsche does not "solve" the question how to determine which value should be permitted and which should not. Rather, his answer would be that this is all well and good, but that such interpersonal comparisons are largely beside the

152. Nietzsche expresses such criticisms of Christianity throughout his works. Though clearly not one of his better works, perhaps his culminating work stating his views on Christianity is FRIEDRICH NiETZSCHE, THE ANTI-CHRIST (R.J. Hollingdale trans. 1968). He soon went mad after writing THE ANTI-CHRIST. Id. at 7. For a balanced treatment, see BERKOWITZ, supra note 7, at 77-83.

153. For a discussion of the standard of treating like cases alike, see David A. Strauss, Must Like Cases Be Treated Alike?, University of Chicago Public Law and Legal Theory Working Paper No. 24, (May 8, 2002), available at http://papers.ssrn.com/sol3/ delivery.cfm/SSRN_ID312180_code020518530.pdf?abstractid $=312180$; JOHN RAWLS, A THEORY OF JUSTICE 237-78 (1971).

154. Joseph Raz argues that the treating like cases alike principle is tautological and impossible to attain. JOSEPH RAZ, THE AUTHORITY OF LAW: ESSAYS ON LAW AND MORALITY 226-27 (1979). I disagree. Consider the following syllogism, inspired by Joseph Raz:

Being or not being Chinese is irrelevant to one's eligibility to enroll in college.

Jane is Chinese.

Therefore, Jane's race is irrelevant to her eligibility to enroll in college.

JOSEPH RAZ, THE MORALITY OF FREEDOM 217-44 (1986). What is "same" or "alike" is the subject of volumes of law on permissible and impermissible categories of difference. For example, to discriminate against entry to university on the basis of race is impermissible because it treats applicants differently, on the basis of an impermissible category. Race discrimination produces impermissible inequality. It fails to treat like cases alike, because race is not a legitimate difference. But to discriminate against entry to a university on the basis of SAT scores is permissible because it treats applicants differently on the basis of a permissible category: success on a standardized test. Discrimination on the basis of standardized test scores produces equality; it treats like cases alike. 
point of a commitment to the noble life. Nietzsche would have no need for fairness or equality other than to facilitate will to power.

Thus, law to Nietzsche should be committed to freedom to engage in will to power. Nietzsche might have the need for law that frees individuals so that they may pursue noble morality. Given the eternal return of the same, we need to "get law right." Nietzsche explains the purpose of law in On the Genealogy of Morals:

Finally, one only has to look at history: in which sphere has the entire administration of law hitherto been at home-also the need for law? In the sphere of reactive men, perhaps? By no means: rather in that of the active, strong, spontaneous, aggressive. From a historical point of view, law represents on earth ... the struggle against the reactive feelings, the war conducted against them on the part of the active aggressive powers who employed some of their strength to impose measure and bounds upon the excesses of the reactive pathos and to compel it to come to terms. Wherever justice is practiced and maintained one sees a stronger power seeking a means of putting an end to the senseless raging of ressentiment among the weaker powers that stand under it.

Written before the introduction of the modern welfare state, Nietzsche's words sound illiberal, even repugnant, to contemporary ears. Nietzsche could be interpreted as rejecting what we call today "social justice" because it manifests ressentiment. ${ }^{156}$ In such an interpretation, Nietzsche forms a classical vision of the rule of law, in the sense that law should promote human freedom, to stop or deter one person or a group of persons from imposing their morality upon others, to prohibit or reduce arbitrary activities that would permit one person from preying on another.

A contrasting interpretation would not place Nietzsche in a political context. Some may be tempted to label Nietzsche "conservative" or "liberal," "right wing" or "left wing." We must avoid trying to pigeonhole Nietzsche into the politics of the present. Nietzsche would have no patience with such political concepts, seeing them as last man thinking, full of bad conscience. Nietzsche's philosophy asks us to transcend politics. To transcend politics we must imagine a world in which social justice is compatible with Nietzsche's noble morality, as a way of improving the human condition.

155. GENEALOGY OF MORALS, supra note 2, Second Essay, $\S 11$.

156. BERKOWITZ, supra note 7 , at 86 . 


\section{NIETZSCHE AND LEGAL UTILITARIANISM}

Utilitarians "are right so rarely that it is really pitiful."

A.

Nietzsche's assault on the utilitarians, those "English psychologists,",158 bears particular relevance for critiquing law and economics, currently the dominant research agenda in the legal academy. ${ }^{159}$ This part of the article applies Nietzsche's critiques of utilitarianism and science to law and economics. Nietzsche's complaints about utilitarianism shed light on the scope and force of economic analysis of law. Nietzsche's critique of science proves relevant because law and economics apply "analytical" or "rigorous" social science methods of economics to law. ${ }^{160}$ Economics follows very much the scientific tradition of Popperian hypothesis testing. ${ }^{161}$ It relies on a rigid distinction between normative and positive analysis. It seeks to "explain," "make findings," and "predict" the consequences or effects of legal rules and processes. ${ }^{162}$ "In law and economics, we have seen some of the most dramatic examples of scientific analysis of law in the post-realist period. Law and economics differs from nineteenth century approaches to legal science, in that law and economics applies economic science to law. As a result, law is not an "autonomous discipline" in this approach, as it was in the other, older and now discredited scientific approach to law. ${ }^{163}$ Hence, a substantial

157. GAY SCIENCE, supra note $3, \S 84$.

158. GENEOLOGY OF MORALS, supra note 2, First Essay, § 1.

159. See generally Robert C. Ellickson, Trends in Legal Scholarship: A Statistical Study, 29 J. LEgal STUd. 517 (2000); James E. Krier \& Stewart J. Schwab, The Cathedral at Twenty-Five: Citations and Impressions, 106 YALE L.J. 2121 (1997); William M. Landes \& Richard A. Posner, Heavily Cited Articles in Law, 71 CHI. KENT L. REV. 825 (1996).

160. See Charles K. Rowley, Social Sciences and the Law: The Relevance of Economic Theories, 1 OXFORD J. LEGAL STUD. 391 (1981); ANALYTIC NARRATIVES 10-13 (Robert H. Bates et al. eds., 1998) (explaining differences between analytical tools of economics and narrative tools of history); KENNETH A. SHEPSLE \& MARK S. BONCHEK, ANALYZING POLITICS: RATIONALITY, BEHAVIOR AND INSTITUTIONS 5-8 (1997) (analytical methods in politics); MELvin J. HINICH \& MICHAEL C. MUNGER, ANALYTICAL POLITICS 3-9 (1997) (analytical methods in politics); see generally JON ELSTER, NuTS AND BOLTS FOR THE SOCIAL SCIENCES (1989); MARTIN HOLlis, THE PHILOSOPHY OF SOCIAL SCIENCE (1994).

161. See Rowley, supra note 160.

162. See supra note 160 .

163. See Richard A. Posner, The Decline of Law as an Autonomous Discipline: 1962. 1987, 100 HARV. L. REV. 761 (1987). 
interdisciplinary movement prevails in legal scholarship, and law and economics is an integral part of that movement. ${ }^{164}$

Legal scholars have disagreed on whether law and economics is utilitarian. ${ }^{165}$ I do not engage this dispute in any appreciable level of sophistication here, although the similarities and intellectual connections seem substantial. Rather, I contend that what Nietzsche said about utilitarianism and science furthers our understanding of the jurisprudential niche of law and economics, regardless of whether law and economics is utilitarian. This part of the article dissects what Nietzsche said about utilitarianism, to expose the main tenets relevant to economics, and to show that Nietzsche produced a serious critique that must be inquired into and that must not be overshadowed by the sometimes harsh and regrettable attacks that Nietzsche visited upon utilitarians and "Englishmen."

$B$.

Nietzsche starts On The Genealogy of Morals with an attack on utilitarianism. ${ }^{167}$ To Nietzsche, what is good (or, in economic terms, "a good") has nothing to do with utility. Nietzsche looks to the origins of the good in noble morality. ${ }^{168}$ Noble morality is internal to the individual and has nothing to do with instrumental effects on others. In dealing with his famous distinction between herd or slave morality and noble morality, Nietzsche used the word "utility" to describe the usefulness of herd morality to the preservation of the herd. ${ }^{169}$ Egoism is a herd or slave morality concept. ${ }^{170}$ People responding to external incentives in order to maximize utility or welfare engage in herd or slave morality. ${ }^{171}$ Utilitarianism in this sense is like religion; religious morality also comes from the outside, but it is revealed in sacred texts. Evolution suffers

164. See supra note 160; see also Nicholas Mercuro \& STEVE G. Medema, ECONOMICS AND THE LAW: FROM POSNER TO POSTMODERNISM (1998).

165. See JUles COLEMAN, MARKETS, MORALS AND THE LAW 95-132 (1998); Richard A. Posner, Utilitarianism, Economics, and Legal Theory, 8 J. LEGAL STUD. 103 (1979); H.L.A. Hart, American Jurisprudence Through English Eyes: The Nightmare and the Noble Dream, 11 GA. L. REV. 969 (1977).

166. For example, in Beyond Good and Evil, Nietzsche is ad hominem in his criticism. He refers to the "English-mechanistic doltification of the world" and "mediocre minds." FRIEDRICH NIETZSCHE, BEYOND GOOD AND EVIL: PRELUDE TO A PHILOSOPHY OF THE FUTURE $\S \S 252-253$ (Walter Kaufmann trans., 1966) [hereinafter BEYOND GOOD AND EVIL].

167. GENEALOGY OF MORALS, supra note 2, Second Essay, §§ 1-3.

168. See supra notes 96-98, 130-41 and accompanying text.

169. BEYOND GOOD AND EVIL, supra note 166, $\$ 201$.

170. Id. $\S 261$.

171. GAY SCIENCE, supra note $3, \S 116$. 
from the same defects; it denies the possibility of noble morality because character is determined by genes, an external force. Nietzsche conceptualized the powerful ideas of his day something like this:

\begin{tabular}{ll} 
Slave Systems & Sources of Normativity \\
\hline Utilitarianism & Pleasure-Pain Principle/Utils
\end{tabular}

Religion

Revelation and Ressentiment

\section{Evolutionary Biology Genes (External Factor)}

Utilitarianism relies on goods and evils, pains and pleasures, in order to sum up the satisfactions of individuals, or to find the greatest good for the greatest number. ${ }^{172}$ In economics, the analogous concepts are "preference" and utility maximization. ${ }^{173}$ Nietzsche throws into question the entire utilitarian project. He could not accept utilitarianism because he rejected the idea that good and evil differ, or at least it could be said that he rejected any simple contrasts or opposing formulas for good and evil. ${ }^{174}$ In The Gay Science, Nietzsche claims that "the strongest and most evil spirits have so far done the most to advance humanity." 175 Nietzsche believed the abolition of suffering to be undesirable, and that "we would rather have it higher and worse than ever."176 To Nietzsche, only the discipline of suffering has brought about improvements in humankind. ${ }^{177}$ Nietzsche finds utilitarianism as "altogether an impossible literature, unless one knows how to flavor it with some malice." 178

It would be a serious misinterpretation to read Nietzsche to mean that he wanted people to suffer or to be evil. To Nietzsche, evil is a concept humans define in society and convention, which has a purpose to improve the human condition. ${ }^{179}$ Too much order in society "puts the passions to sleep." 180 Evil reawakens "the sense of comparison, of contradiction, of the pleasure in what is new, daring, untried; they compelled men to pit opinion against opinion, model against model."181

172. BEYOND GOOD AND EVIL, supra note $166, \S 260$.

173. See DAVID M. KREPS, A COURSE IN MICROECONOMIC THEORY 18-37 (1990).

174. See supra notes $179-86$ and accompanying text.

175. GAY SCIENCE, supra note $3, \S 4$.

176. BEYOND GOOD AND EVIL, supra note $166, \$ 225$.

177. Id.

178. Id. $\S 228$ (emphasis in original).

179. GAY SCIENCE, supra note $3, \S 4$.

180. Id.

181. Id. 
Nietzsche continues, that what is new is always evil because it "wants to conquer and overthrow the old boundary markers and the old pieties."182 To Nietzsche, "only what is old is good." In this way, Nietzsche critiques the simple good-evil or pain-pleasure dichotomy that utilitarians propose. "[E]vil instincts are expedient, species-preserving, and indispensable to as high a degree as the good ones; their function is merely different." 184 Nietzsche is saying something similar to George Bernard Shaw's " $[\mathrm{t}]$ he reasonable man adapts himself to the world: the unreasonable one persists in trying to adapt the world to himself. Therefore all progress depends on the unreasonable man." 185 To Nietzsche, hardship, striving, unreasonableness - these are all attributes that are required for the enhancement of the human condition. ${ }^{186}$

Nietzsche did not value happiness or welfare; these are not the big issues to Nietzsche. Rather, to Nietzsche, focusing on these values stops people from realizing their full potential. ${ }^{187}$ Nietzsche criticized utilitarianism as concerned with trivial matters. ${ }^{188}$ To Nietzsche, measurements of human welfare that utilitarianism uses fail to address important problems; "there are higher problems than all problems of pleasure, pain, and pity; and every philosophy that stops with them is a naïveté." 189 Pain and pleasure are "mere epiphenomena and wholly secondary." 190 Well-being or welfare-maximization are states that make humankind "ridiculous and contemptible."191

C.

Law and economics assumes that people are rational, which means that people act in their own self-interest to maximize their own satisfaction. ${ }^{192}$ Behavioral economists and cognitive scientists are producing research that throws the rationality assumption into

182. Id.

183. Id.

184. Id.

185. GEORGE BERnARd SHAw, MAN AND SupERMAN: A COMEDY AND A PHILOSOPHY 238 (1903).

186. Nietzsche's complaints about equality apply here too. See supra notes $146-57$ and accompanying text.

187. BEYOND GOOD AND EVIL, supra note $6, \S 225$.

188. Id.

189. Id.

190. Id.

191. Id.

192. See generally GARY S. BECKER, THE ECONOMIC APPROACH TO HUMAN BEHAVIOR 3-14 (1976). 
question. ${ }^{193}$ Using the idea of "bounded rationality," economists model the effects of uncertainty and imperfect information on human choice. ${ }^{194}$ Some of these economic models accept that people "satisfice," meaning that they "follow[] ordinary habits and rules of thumb so long as they yield satisfactory results, even if an alternate set of procedures would in theory be superior." 195

The model of bounded rationality and "satisficing" finds some support from Nietzsche; he would accept that knowledge is not rational, scientific, ahistorical or analytical. ${ }^{196}$ Likewise, to Nietzsche, logic originates in illogic. ${ }^{197}$ "Innumerable beings who made inferences in a way different from ours perished; for all that, their ways might have been truer." 198 Those who were too deliberate and cautious, not finding things to be equal, perished. Those who survived considered two circumstances equal when there is nothing logical in equality because nothing is equal. ${ }^{199}$ Nietzsche's basic point is consistent with behavioral economics, in its claim that logic is not solely or even primarily about rational calculation, but about "satisficing" or rule of thumb thinking about the world, in which error educates.

Nietzsche, however, is dissatisfied with error-produced understanding. To Nietzsche, knowledge stems from a clash between the "impulse for truth" and "life-preserving errors." ${ }^{201}$ Nietzsche would prefer that people get out of their error-produced ruts; this is where his normative ethics come in, his will to power and eternal recurrence, which calls upon individuals to enhance their condition beyond traditional. understanding. ${ }^{202}$

193. Cass R. Sunstein, Introduction, in BEHAVIORAL LAW AND ECONOMICS 3-7 (Cass R. Sunstein, ed., 2000).

194. FOUNDATIONS OF THE ECONOMIC APPROACH TO LAW 267-69 (Avery Wiener Katz, ed., 1998) [hereinafter FOUNDATIONS].

195. Id. at 268.

196. See GAY SCIENCE, supra note $3, \S 110$.

197. Id. § 111.

198. Id. Nietzsche offers as an example that one could be too deliberate in deciding whether a tiger is dangerous as compared to a snake. Those who exercised lower levels of logical power would consider the element of "danger" to be equal here, while the more deliberate would not and would perish. Of course, Nietzsche ignores that it may be "logical" to presume equality of danger in such circumstances; it is logical to focus on relevant facts and ignore the irrelevant ones. Id.

199. Id.

200. FOUNDATIONS, supra note 194, at 268.

201. See GAY SCIENCE, supra note $3, \S 111$.

202. See supra notes $98-129$ and accompanying text. 
$D$.

In The Gay Science, Nietzsche examines altruism and lays the foundation for his later work on ressentiment and bad conscience. ${ }^{203}$ Nietzsche sees a fundamental contradiction in altruism. ${ }^{204} \mathrm{He}$ attacks the idea that altruism is virtuous. ${ }^{205}$ To be altruistic, one's actions must be "selfless," "unegoistic," and detrimental to the person who possesses the virtue in question, but to Nietzsche, altruism has none of these qualities. ${ }^{206}$ The contradiction can be viewed from the perspectives of the giver and the recipient. The giver benefits from altruism, as does the recipient, the "neighbor." 207 Nietzsche stated, "[i]f the neighbor himself were 'selfless' in his thinking, he would repudiate this diminution of strength, this mutilation for his benefit; he would work against the development of such inclinations, and above all he would manifest his selflessness by not calling it good!",208

Nietzsche's critique of altruism appears, no doubt coincidentally, similar to the contemporary economic analysis of altruism. An economist assumes that people act rationally to maximize their own utility. ${ }^{209}$ Altruism can be a Nash equilibrium strategy when the best possible strategy that a player $\mathrm{X}$ can take is altruistic, given the strategies that player $X$ expects player $Y$ to take..$^{210}$ In other words, people will coordinate around altruism when it makes them better off. Consider a simple family example. A parent is better off making gifts to his child so that the child can attend college, when the parent has a preference that the child attend college. The child is better off too, if her welfare is increased. Evolutionary biologists make similar findings about nonhuman behavior. ${ }^{211}$

Altruism is an entire research agenda and not susceptible to full analysis here. I have omitted entirely any mention of research on

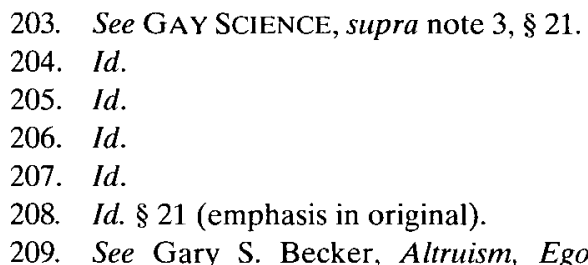
Sociobiology, 14 J. ECON. LIT. 817, 818-22 (1976). A substantial amount of economics literature exists on altruism, but Becker's work pioneered the field. Becker developed a model in which he showed that even egoists have an incentive to be altruistic when they benefit from altruism. Although Becker relied on price theory, there is a game theoretical aspect to all of this.

210. For the fundamentals of game theory, see ERIC RASMUSEN, GAMES AND INFORMATION (3d ed. 2001).

211. For a layman's explanation, see RICHARD DAWKINS, THE SELFISH GENE 4-5 (1989). 
altruism in other social sciences, such as in psychology and sociology, and I have not engaged the philosophical literature on altruism. The point is that Nietzsche, writing in the nineteenth century, substantially presaged most of the later research in economics that is so very influential in legal scholarship.

E.

The origin of cooperation among humans has been the subject of considerable theorizing by both philosophers and economists. ${ }^{212}$ The characteristics of cooperation are important in a legal utilitarian calculus because the law centers on dispute resolving. Understanding the conditions in which people cooperate can tell us something about the origin of legal rules. Nietzsche was not interested in learning the conditions in which people cooperate, but he provides some guidance in his discussion of the origin of society-preserving morals. ${ }^{213}$

At the beginning of the Second Essay in On the Genealogy of Morals, Nietzsche poses the question: "To breed an animal with the right to make promises-is not this the paradoxical task that nature has set itself in the case of man? Is it not the real problem regarding man?"214 Nietzsche then goes on to explain that man's conscience originates in cruelty that humans have visited upon one another over the years. ${ }^{215}$ Nietzsche explained that his second essay was based only on conjecture. ${ }^{216}$ Anecdotal evidence supports Nietzsche's theory on the medieval origin of common law legal rules on the transfer of real property. ${ }^{217}$ Though the

212. The literature is vast, but for a start, see ROBERT AXELROD, THE EVOLUTION OF COOPERATION (1984); ROBERT AXELROD, THE COMPLEXITY OF COOPERATION: AGENT-BASED MODELS OF COMPETITION AND COLLABORATION (1997); ElINOR OSTROM, GOVERNING THE COMMONS: THE EVOLUTION OF INSTITUTIONS FOR COLLECTIVE ACTION (1990). These sources are rational-choice influenced and influential in the economics literature.

213. See infra notes $214-23$ and accompanying text

214. GENEALOGY OF MORALS, supra note 2, Second Essay, $\S 1$ (emphasis in original).

215. Id. §3. Nietzsche says:

Man could never do without blood, torture, and sacrifices when he felt the need to create a memory for himself; the most dreadful sacrifices and pledges (sacrifices of the first-born among them), the most repulsive mutilations (castration, for example), the cruelest rites of all the religious cults (and all religions are at the deepest level systems of cruelties)-all this has its origin in the instinct that realized that pain is the most powerful aid to mnemonics.

Id.

216. Id. $\$ 6$.

217. An important attribute of real property is the ability to transfer it to successive owners. RoBERT COOTER \& ThOMAS ULEN, LAw AND ECONOMICS 139 (3d ed. 2000). Transfers require the creation of a record of ownership. Id. In the Middle Ages, few people could read, and no agencies of government existed as we know them today, 
livery of seisin terminology has survived into the twentieth century, records of title held by the appropriate government bodies are the means by which property transfers are recorded, and the original ceremony is long forgotten.

Nietzsche contended that cruelty leads to conscience, which leads to morality. ${ }^{219}$ Social fabric and moral and legal obligation come from "blood" of passion and not reason: "It was in this sphere then, the sphere of legal obligations, that the moral conceptual world of 'guilt,' 'conscience,' 'duty' 'sacredness of duty' had its origin: its beginnings were, like the beginnings of everything great on earth, soaked in blood thoroughly and for a long time."220 Nietzsche argues that retribution is the origin of morality:

To ask it again: to what extent can suffering balance debts or guilt? To the extent that to make suffer was in the highest degree pleasurable, to the extent that the injured party exchanged for the loss he had sustained, including the displeasure caused by the loss, an extraordinary counterbalancing pleasure: that of making suffer $-\mathrm{a}$ genuine festival, something which, as aforesaid, was prized the more highly the more violently it contrasted with the rank and social standing of the creditor. ${ }^{221}$

He then clarifies the origins of the moral human in the exchange relationship of debtor-creditor:

[T] he feeling of guilt, of personal obligation, had its origin ... in the oldest and most primitive personal relationship, that between buyer and seller, creditor and debtor; it was here that one person first encountered another person, that one person first measured himself against another . . . Setting prices, determining values, contriving equivalences, exchanging - these preoccupied the earliest thinking of man to so great an extent

\footnotetext{
designed to preserve records of title. To record "title" to land, a ceremony known as "livery of seisin" was conducted in which seller handed the buyer a piece of the turf and a twig from the land. Id. The folklore on livery of seisin is that the ceremony included the thrashing of a child who had witnessed the passing of the turf and the twig. Id. The child was thrashed severely so that he would remember that day forever, thus creating a living record of the transfer. Id.; see also Jeffrey Evans Stake, The Uneasy Case for Adverse Possession, 89 GEO. L.J. 2419, 2440 (2001). I use the words "folklore" and "anecdotal" because of the debateable historical accuracy of these aspects of the ceremony relating to the child witness. See S.E. Thorne, Livery of Seisin, 52 LAW QUARTERLY REVIEW 345 (1956) (not mentioning this aspect of ceremony but discussing the need for observance by witnesses).

218. COOTER \& ULEN, supra note 217.

219. GENEALOGY OF MORALS, supra note 2, Second Essay, $\$ 6$ (emphasis in original).

220. Id. (emphasis in original).

221. Id. (emphasis in original).
} 
that in a certain sense they constitute thinking as such: here it was that the oldest kind of astuteness developed; here likewise, we may suppose, did human pride, the feeling of superiority in relation to other animals, have its first beginnings. ${ }^{222}$

Thus, humans are valuating, calculating agents similar in nature to the utility maximizing persons of utilitarianism and law and economics.

Nietzsche's propositions about the origins of morals share similarities with theorizing economists on why and how people cooperate. These economists are looking for the incentives that assumedly rational or boundedly rational humans require in order to engage in contract or society. Nietzsche was not looking for such a theory, so the comparisons are imprecise, but his morality discussion tells us something about what he saw as a relationship among humans, therefore the claims are worthy of comparison.

The economist Oliver Williamson makes an argument similar to Nietzsche's argument. Williamson is not looking for the basis or morality. His limited theory searches for the factors that support cooperation. His theory is that exchange is based on the idea of taking hostages. In his article, Credible Commitments: Using Hostages to Support Exchange, Williamson explains that the origins of cooperation are in the bargaining exchange over a hostage. ${ }^{223}$

The hostage relationship sets up a relationship similar to Nietzsche's debtor-creditor relationship. Williamson does not discuss, however, the hostage theory anthropologically, or from a natural history viewpoint. ${ }^{224}$ But the connection to Nietzsche's theory seems clear. People engage in debtor-creditor relationships all the time. If one wants to buy a house, one becomes a debtor and gives the creditor bank a hostage-a security interest in one's home. Security interests have their origins in possessory pledges of property in which the creditor holds the property until the debt is paid.

Another fruitful comparison is Nietzsche's origins of morals with the prisoner's dilemma. ${ }^{225}$ Here, the infliction of tit-for-tat sanctions in an

222. Id. $\$ 8$ (emphasis in original).

223. See Otiver E. Williamson, Credible Commitments: Using Hostages to Support Exchange, 83 AM. ECON. REV. 519-20 (1983). Medieval kings guaranteed peace among themselves by exchanging their children. When a king's child was in the court and country of his rival, he was less likely to start a war. A good hostage is one that the hostage-giver values highly and the hostage-taker values little. If the king was to give his rival diamonds, then deterrence is weak because his rival will place a high value on diamonds, will go to war, and will keep the diamonds. COOTER \& ULEN, supra note 217, at 221.

224. Williamson's approach is consistent with the ahistorical approach of economics as an "analytical" social science.

225. See generally ROBERT AXELROD, THE EVOLUTION OF COOPERATION (1984). 
infinitely repeating game produces cooperation. ${ }^{226}$ Again, the origin of cooperation lies in a negative sanction. Even Nash equilibrium, a strategy in game theory in which a player takes the best move he can, given the move the other player is expected to take, seems to have as its origins in the measuring and evaluating in the "debtor-creditor" relationship that Nietzsche explores. ${ }^{227}$

I have taken some liberties with these theories, and have examined them in ways that economics does not permit. But the basic point herethat "sanctions," "prices," or "payoffs" form a base for Nietzsche's morality as well as for economic analysis - suggest that Nietzsche was not so far away from law and economics approaches as one would typically suspect.

$F$.

Nietzsche's "pitiful" quote, set forth at the beginning of the second part of the Article, comes from a discussion of poetry in The Gay Science. ${ }^{228}$ Nietzsche poses the question whether utilitarianism is an adequate or complete theory of human behavior, when it cannot account for something like poetry. ${ }^{229}$ Here, Nietzsche says he sides with the utilitarians, in that poetry in ancient times had great utility, to influence the gods. ${ }^{230}$ The utility in poetry originated in superstition. ${ }^{231}$ Poetry was useful to the ancients. ${ }^{232}$ It represents an older form of utilitarianism designed to impress deities. ${ }^{233}$ Nietzsche's utilitarian analysis of poetry can hardly be taken literally. Nietzsche was likely offering a critique of utilitarianism: try as it may to be scientific and rational, its origins are primordial, in superstition, in the approach of ancient rhyme whose rhythm is intended to serve as supernatural. ${ }^{234}$

In Book Three of The Gay Science, Nietzsche sets forth the core of his epistemological thinking. Although this part of The Gay Science says very little about utilitarianism, it offers a powerful examination of the concepts of science and explanation, relevant for reflecting on methodologies used in legal scholarship. ${ }^{235}$

226. Id. at 27.

227. See Friedrich NiETzSChE, Human All ToO Human $\S 92$ (Walter Kaufmann trans., 1966).

228. See supra note 157 and accompanying text.

229. GAY SCIENCE, supra note $3, \S 84$

230. Id.

231. Id.

232. Id.

233. Id.

234. Id.

235. Id. $\S \S 167-220$. 
Explanation is impossible, according to Nietzsche. ${ }^{236}$ Nietzsche contended that we are better at describing states of affairs, but we are no better at explaining them than we were in pre-modern times. ${ }^{237}$ Nietzsche was ahead of his time in his critique of scientific explanation. "How should explanations be at all possible when we first turn everything into an image, our image!" 238 As for cause and effect, "in truth we are confronted by a continuum out of which we isolate a couple of pieces ..."239 Here, Nietzsche presages much of the postmodern attack on the use of scientific method in the social sciences, including the problem of false consciousness, and the weaknesses of empiricism in the social sciences, in which we try to isolate phenomena and control for others in order to develop the idea of statistical inference and probabilistic analysis.

To put Nietzsche in the proper perspective, his criticism of science was not of science per se, and particularly not of the natural sciences. Nineteenth-century continental Europeans had a far broader notion of science than do twentieth-century Americans. Nietzsche's critique of science centered on the blind application of the scientific method to social phenomena and art. The Germans, for example, conceptualized law as a science in the nineteenth-century, and the idea that law is a science still clings in the official version of German law, in the German legal academy, in the courts, and among legal practitioners trained in the academy. ${ }^{240}$ In the juridical science of continental jurists, determining what is the appropriate legal rule is a scientific enterprise, the product of reason; the contents of legal rules can be determined autonomously as a scientific endeavor. ${ }^{241}$ German juridical science (or French for that matter) is not mathematical, but systematic. Economic analysis of law tends towards the mathematical but often is not, and a significant economically influenced legal scholarship exists, which uses economics as a kind of utilitarian moral philosophy to inquire about the effects of law. ${ }^{242}$

Nietzsche was an early critic of such approaches as a kind of scientism. In The Gay Science, Nietzsche used the word "faith" to describe scientific

236. Id. $\$ 172$.

237. See id.

238. Id. $\S 112$ (emphasis in original).

239. Id.

240. See, e.g., John Linarelli, Anglo-American Jurisprudence and Latin America, 20 FORDHAM INT'L L.J. 50, 67 (1996).

241. Id.

242. See generally David A. Hoffman \& Michael P. O'Shea, Can Law and Economics Be Both Practical and Principled?, 53 ALA. L. REV. 335 (2002). 
method. ${ }^{243}$ In science, theories are always subject to revision through hypothesis testing and falsification. But such theories, in Nietzsche's philosophy, are subject to prior convictions, things a priori and necessary for the scientific method to exist as a discipline. Science does not exist without presuppositions. The particular presupposition required is that truth is needed and more important than everything else. ${ }^{244}$ Science rests on a faith in truth. ${ }^{245} \mathrm{He}$ is critical of faith in "a 'world of truth' that can be mastered completely and forever with the aid of our square little reason." ${ }^{246}$ Nietzsche says:

What? Do we really want to permit existence to be degraded for us like this-reduced to a mere exercise for a calculator and an indoor diversion for mathematicians? Above all, one should not wish to divest existence of its rich ambiguity: that is a dictate of good taste, gentlemen, the taste of reverence for everything that lies beyond your horizon. ${ }^{247}$

To Nietzsche, scientific method inquires about only "the most superficial and external aspect of existence-what is most apparent, its skin and sensualization .... ,248 Such a scientific interpretation of the world might be "one of the most stupid of all possible interpretations of the world," in other words, "the poorest in meaning." "249 Nietzsche's concern was that if we subjected the social world or art to the scientific method, we would have an "essentially mechanical world," which is "an essentially meaningless world." 250

The first essay in Beyond Good and Evil is entitled "On the Prejudices of Philosophers." the essay, Nietzsche questions analytical and systematic methods. Nietzsche was passionate in his dislike of German systematic reasoning. ${ }^{252}$ These methods reflect what Nietzsche elsewhere calls the bad conscience. On the surface, the scholar's work is articulated and presented as a process of disinterested discovery, "self-development of a cold, pure, divinely unconcerned dialectic." 253 The reality is that it is not analytical. "[I]t is an assumption, a hunch, indeed a kind of

243. GAY SCIENCE, supra note $3, \S \S 344,373$.

244. Id.

245. Id. $\$ 344$.

246. Id.

247. Id. (emphasis in original).

248. Id.

249. Id. (emphasis in original).

250. Id.

251. BEYOND GOOD AND EVIL, supra note $166, \S \S 1-23$.

252. Id. § 11.

253. Id. $\S 5$. 
'inspiration' - most often a desire of the heart that has been filtered and made abstract - that they defend with reasons they have sought after the fact." ${ }^{254}$ Analysis is a way to mask prejudice. ${ }^{255}$ Logicians have superstitions, logic is therefore superstitious. ${ }^{256}$ Narrative is more important than method; philosophy is the "personal confession of its author and a kind of involuntary or unconscious memoir."257

In the essay entitled "Natural History of Morals" in Beyond Good and Evil, Nietzsche continues his attack on reason. ${ }^{258}$ Reason cannot explain what is good. It is instrumental; reason serves good. Nietzsche criticizes morality as irrational, what Christianity calls faith, Nietzsche deems "herd" instinct. ${ }^{259}$ Authority does not concede to reason; it is the other way around. ${ }^{260}$

Nietzsche continues his critique of reason and science in his essay "We Scholars" in Beyond Good and Evil. ${ }^{261}$ Here he asserts the importance of experience over reason, and emphasizes that philosophy cannot be taught, because one must know it from experience. ${ }^{262}$ Nietzsche's metaphor is that philosophy, or, to generalize, learnedness, without experience is like a blind man examining colors. ${ }^{263}$ In response to

254. Id. § 5; see Hal R. Varian, How to Build an Economic Model in Your Spare Time, in PASSION AND CRAFT: ECONOMISTS AT WORK (Michael Szenberg ed., Univ. of Michigan Press 1997) (copy on file with author). In advising economics graduate students on how to develop an economic model, Varian explains:

I think that you should look for your ideas outside the academic journals - in newspapers, in magazines, in conversations, and in TV and radio programs. When you read the newspaper, look for the articles about economics . . . and then look at the ones that aren't about economics, because lots of the time they end up being about economics too. Magazines are usually better than newspapers because they go into issues in more depth. On the other hand, a shallower analysis may be more stimulating: there's nothing like a fallacious argument to stimulate research. Conversations, especially with people in business, are often very fruitful. Commerce is conducted in many ways, and most of them have never been subjected to a serious economic analysis. Of course you have to be careful not to believe everything you hear - people in business usually know a set of rules that work well for running their own business, but they often have no idea of where these rules come from or why they work, and this is really what economists tend to find interesting. In many cases your ideas can come Id. from your own life and experiences.

255. See BEYOND GOOD AND EVIL, supra note 166, § 5, at 12-13.

256. Id. § 17 , at 24 .

257. Id. $\S 6$, at 13 .

258. See generally id. pt. 5 .

259. See supra notes $169-72$ and accompanying text.

260. See BEYOND GOOD AND EVIL, supra note 166, § 191, at 103-04.

261. See generally id. pt. 6.

262. Id. $\$ \$ 204,213$, at $121,139$.

263. See id. $\$ 204$, at 121. 
utilitarian criticisms of philosophy as dealing with questions that cannot be answered and that were not worth answering, Nietzsche referred to the "color blindness of the utility man who sees nothing in philosophy but a series of refuted systems and a prodigal effort that 'does nobody any good.",264

\section{CONCLUSION}

Nietzsche remains a mysterious and misunderstood figure in legal philosophy. His intractability to legal theorists is undoubtedly the result of his acerbic prose, his iconoclasm, and his heaping of scorn on Socrates, Christianity, Judaism, Enlightenment, democracy, socialism, women and their emancipation, the notion of human equality fundamental to liberalism, and just about everything else associated with modernity. ${ }^{265}$ His ethical principles and his insights on the human condition make him an important philosopher worthy of study by legal theorists. Nietzsche provides an ethical and critical perspective about science and reason that offers a great deal to assist us in understanding how to theorize and engage in interdisciplinary inquiries about law. ${ }^{266}$ What Nietzsche said about classical studies is relevant to our thinking about him in the context of legal theory: "I do not know what meaning classical studies could have for our time if they were not untimely - that is to say, acting counter to our time and thereby acting on our time and, let us hope, for the benefit of a time to come.,"267

264. Id. at 122 (emphasis in original).

265. See Berkowitz, supra note 7, at 1.

266. See generally Friedrich Nietzsche, On the Uses and Disadvantages of History for Life, in FRIEDRICH NIETZSCHE, UNTIMELY MEDITATIONS (R.J. Hollingdale trans., 1997).

267. Id. at 60 . 